\title{
The Cashless Economy in Vietnam - The Situation and Policy Implications
}

\author{
Hoang Ha*
}

\author{
University of Economics - The University of Danang, 71, Ngu Hanh Son, Da Nang 55000, Vietnam
}

\begin{abstract}
A cashless economy is one where purchases and transactions are done mainly by electronic means and seldom by cash (Ejiofor and Rasaki 2012). Vietnam has now joined the Better Than Cash Alliance (Betterthancash.org 2017 ) and the ambitious goal of the government is in 2020, the proportion of cash on total payment means is lower than $10 \%$ (Vu 2018). Non-cash payment - a pillar of the cashless economy - has become a very popular means of payment in the world and is expanded used commonly in Vietnam. Through researching payment via mobile banking (MB), we surveyed of over 140 people in Da Nang city to find out demographic characteristics, the most used cashless payment features, as well as the ratio of cashless payment to total spending. The situation was evaluated and several important policy implications were proposed for Vietnamese government.
\end{abstract}

Keywords: Cashless economy, Non-cash payment, Shadow economy.

\section{INTRODUCTION}

The rapid development of the Internet, the speed of data transfer, smartphones ... is pushing the conversion to a cashless economy in many parts of the world as a sprint race. This process has many benefits for governments, central banks, businesses and especially technology companies and payment card companies. Developments in technology financial transaction does not use cash it raises interesting questions for policymakers and financial institutions on the conformity of the agreement existing institutional and availability have the tools to ensure financial stability, effectiveness and usefulness efficacy of monetary policy. The Vietnamese government has launched a motivated strategy to reduce domestic cash transactions to less than $10 \%$ of total market transactions in 2020 . Accordingly, at least $70 \%$ of water service providers, electronics and telecommunications will receive cashless payments from individuals and households. Furthermore, the goal is to at least $50 \%$ of all households in Vietnam use electronic payments for daily transactions in 2020 .

Through researching a very popular tool of noncash payment - via mobile banking, we conducted a survey of more than 140 people in Da Nang City to explore the demographic characteristics, the most used cashless payment features, and the ratio of cashless payments to total spending. From there, assess the situation and make policy implications for the goal of becoming a cashless economy of Vietnam.

*Address correspondence to this author at the University of Economics - The University of Danang, 71, Ngu Hanh Son, Da Nang 55000, Vietnam; Tel: +84 935354966; Fax: +84 236 3836255; E-mail: hahoang@due.edu.vn
This study aims to find answers to the following research questions:

- What is the cashless economy and its impact on the entire economy?

- What is the situation of the cashless economy in Vietnam?

- What are proposed recommendations for achieving the goal to become a cashless economy?

\section{LITERATURE REVIEW AND RESEARCH METHOD}

\subsection{Literature Review}

\subsubsection{The Cashless Economy}

Definition

A cashless economy is a place where purchases and transactions are made primarily electronically and rarely in cash (Ejiofor and Rasaki 2012). One of the pillars of the cashless economy is non-cash payment, but through electronic money transfers, bank transfers or payment by cheque. Accordingly, goods and services are traded effectively without cash. Effectiveness of non-cash payments for an economy can be analyzed using innovation diffusion theory Diffusion of Innovation Theory (DOI) (Tee and Ong 2016). Introduced by Roger, this concept attempted to explain how innovation has spread to members of a social system over time (Rogers 1995). According to $\mathrm{DOI}$, the application of a new idea or innovation is due to interpersonal interaction through interpersonal networks. Then popular is the spread of the nonpayment of cash, where consumers seek ways 
transactions improved process and convenient, while businesses seeking to generate new revenue. The dissemination of cashless payments will lead to the application of cashless transactions in society or the community. As a result of the popularity of non-cash payments depends on how quickly society is willing to accept non-cash payments through the various stages of the renewal process, should lead to the application of different non-cash payments will be in different societies.

Back in the 1980s, a study found that in the 1960s and 1970s, the application of electronic money transfers would work as a substitute for cheques and cash as the main payment method in the United States (Fox 1980). Today, the use of electronic payments has continued to increase due to its convenience, safety and fast payment method. Oyewole, El-Maude et al. (2013) found that the adoption of electronic payments would positively affect economic and trade growth in Nigeria. Hasan, De Renzis et al. (2012) examined the basic relationship between the application of electronic retail payment and the general economic growth in 27 European countries during 1995 - 2009. They found that switching to efficient e-retail payments stimulated economic growth, consumption and trade in general. However, the impact of credit and debit card payments, money transfers and cheque payments on the economy is relatively low.

Electronic payments will replace widespread cheque payments, but cash-based payments will exist to a considerable extent (Liao and Handa 2010). Although technological advances have enabled innovation and innovation in electronic payment systems (Oyewole, El-Maude et al. 2013), from basic ATM card transactions to online credit transfers, debits direct, payment cards and cheque, the issues related to security; the user is not proficient in information technology and phishing emails are some disadvantages of applying the non-payment cash. Losing money and the danger of personal information undermines consumer confidence in electronic payment.

\section{The Cashless Economy in Vietnam}

Results of the survey The status of cashless payment in 6 ASEAN countries (including Singapore, Thailand, Malaysia, Indonesia, Cambodia and Vietnam) conducted by IDG ASEAN shows that the rate of payment via card (Credit / Debit card) accounted for $38 \%$ of total transactions, via mobile banking accounted for $30 \%$ and via electronic wallets (E-wallet) accounted for $28.4 \%$. On average, the percentage of non-cash payment transactions in 6 ASEAN countries is $36 \%$ and $64 \%$ is cash. Vietnam has a cash payment rate of $79 \%$ and non-cash payment is $21 \%$, ranked $5 / 6$ in the region.

According to data from the Central Institute for Economic Management (CIEM), up to now, the development of cashless payment in Vietnam, especially in agriculture and rural areas, is still limited. The proportion of non-cash payment / total means of payment is low, accounting for only $11.49 \%$. The rate of cash use is very high, accounting for nearly $90 \%$ of spending; of which $99 \%$ for items below 100,000 VND (about 4 US Dollars). Nearly $85 \%$ of transactions at ATMs are simply withdrawals (Anh T, 2019).

According to the State Bank of Vietnam, the number of people with current bank accounts is 45.8 million / 92.6 million, equivalent to about half of the population. Regarding non-cash payment activities, by the end of September 2019, Vietnam had 32 non-bank organizations licensed to provide intermediary payment services, most of them providing services. e-wallets, electronic payment gateways, support for authorized payment, electronic money transfer. However, the ratio of non-cash payment transactions to total retail sales is still low, and the development of non-cash payment activities is limited.

The reason is that the financial and technical infrastructure system is mainly concentrated in large centers and cities and has not reached the difficult and backward areas. In addition, the rate of borrowing through financial institutions still has many forms of informal borrowing; digital finance has not yet developed, and the number of people using digital financial services is low. (Hong 2019)

\subsubsection{The Benefits of a Cashless Economy}

Increase the Efficiency of the Economy

Today, the speed, convenience and safety of noncash payments are being paid attention to by the government because the effectiveness of payments greatly affects the efficiency of mobilizing and allocating social capital. This also shows the development or stagnation of a nation's economy. In a cashless economy, the government will have benefits such as better tax evasion control and illegal cash flows. The central bank has better control over the money supply, thereby making the monetary policy more appropriate. The cashless economy provides 
transparency in business transactions and this will inevitably lead to an increase in tax revenue and an increase in infrastructure development which is important for economic development. A study by Zandi, Singh et al. (2013) investigated whether the long-term transition to credit and debit cards stimulated economic growth in 56 countries around the world. They found that electronic card payments can increase efficiency and boost the economy's consumption. Moreover, the application of electronic transactions is essential for transparency, accountability and reduction of cashrelated fraud, the key elements of economic growth and development (Mieseigha and Ogbodo 2013).

\section{Reduce Crime}

There is evidence of a causal relationship between cash and crime involving cash. A recent study found that reducing cash flow reduced overall crime rates, and rates for theft and assault. Local crime rates in poor neighborhoods have improved after introducing card-based social security benefits that are believed to reduce the amount of cash on the street. Because cash is so important to pursuiting illegal actions, this plays a role in curbing the root cause of street crime, slowing down the violation rate. Less cash means fewer crimes (Wright, Tekin et al. 2017).

\section{Reduce the Size of the Shadow Economy}

The shadow economy, also known as the informal economy, has long been recognized and plays an increasingly important role in economies around the world, especially for developing countries like Vietnam. In recent years, the strong growth of Vietnam's economy has recorded the development and significant contribution of informal economic activities. Recently, the General Department of Statistics (Ministry of Planning and Investment) has submitted to the Prime Minister the Project of Statistics of unregulated economic areas (also called informal economy) in order to help the Government to introduce appropriate policies in the future. The shadow economy is intrinsically difficult to measure because agents involved in underground economic activities try to stay undetected. However, the demand for information on the extent of the shadow economy and its development over time is concerned by its impact on politics and the economy as a whole (Medina and Schneider 2018). Understanding the whole economic activity, including the production of formal and informal goods and services, is essential for the formulation of economic policies to cope with increasing fluctuations. Moreover, the size of the shadow economy is an important input for policymakers to estimate the level of tax evasion and can therefore make decisions to bring the shadow economy under control. Although the ratio of cash payments is not a reliable indicator of the size of the shadow economy, the abolition of cash will increase the cost of illegal payments and may then reduce the tissue of the shadow economy. Without cash, the shadow economy could be reduced by $10 \%$ to $20 \%$ (Schneider 2017).

\subsection{Research Method}

The study was conducted based on a combination of two methods: qualitative research and quantitative statistical descriptive research. Previous studies on the cashless economy have been carefully studied to build a theoretical basis and set up survey questions for the next step which is quantitative statistical descriptive research. Through researching a very popular tool of non-cash payment is the form of payment via mobile banking (MB), we conducted a survey of over 140 people in Da Nang City to understand the demographic characteristics, the most used cashless payment features, and the ratio of cashless payments to total spending. We contacted potential respondents and inquired whether they had mobile banking usage experience. Only those users with mobile banking usage experience were selected as the targets and asked to fill the questionnaire. The collected data will be processed and put into SPSS software to perform descriptive statistical analysis. From there, assess the situation and propose policy implications for achieving the goal of becoming a cashless economy of Vietnam.

\section{RESEARCH RESULTS AND DISCUSSION}

\subsection{Research Results}

\subsubsection{Characteristics of Research Subjects}

The demographic structure of the data shows diversity in age, occupation, average income and education level. From that, it is possible to identify the research sample that is guaranteed to be representative of those who use an extremely important payment instrument in a cashless economy the mobile banking application, which is a tool to help improve efficiency and increase the satisfaction of users of banking services in a digital age.

In general, most of the interviewees were new to non-cash payment, showing that this payment method is still quite new. With the rate of more than $60 \%$ of respondents saying their MB usage time is less than 1 
Table 1: Demographic Structure of Data

\begin{tabular}{|c|c|c|c|}
\hline \multicolumn{2}{|c|}{ Characteristics } & \multirow{2}{*}{$\begin{array}{c}\text { Number (person) } \\
66\end{array}$} & \multirow{2}{*}{$\begin{array}{c}\text { Ratio } \\
46.5 \%\end{array}$} \\
\hline Gender & Male & & \\
\hline \multirow[t]{3}{*}{ Age } & $18-25$ years old & 70 & $49.3 \%$ \\
\hline & 26 - 30 years old & 28 & $19.7 \%$ \\
\hline & over 41 years old & 15 & $10.6 \%$ \\
\hline \multirow[t]{3}{*}{ Job } & Student & 63 & $44.4 \%$ \\
\hline & Staff & 24 & $16.9 \%$ \\
\hline & Business owners & 15 & $10.6 \%$ \\
\hline \multirow{4}{*}{ Average income } & From 5 - 10 million VND & 27 & $19 \%$ \\
\hline & From 10 - 15 million VND & 18 & $12.7 \%$ \\
\hline & From $15-20$ million VND & 12 & $8.5 \%$ \\
\hline & Over 20 million VND & 14 & $9.9 \%$ \\
\hline \multirow[t]{4}{*}{ Academic level } & High school graduation & 13 & $9.2 \%$ \\
\hline & Studying at University & 65 & $45.8 \%$ \\
\hline & Graduate & 52 & $36.6 \%$ \\
\hline & Postgraduate & 12 & $8.5 \%$ \\
\hline
\end{tabular}

(Source: Analysis of survey data in 2019 by the author).

Table 2: Duration of Using MB

\begin{tabular}{|c|c|c|}
\hline Time using MB & Number (person) & Ratio \\
\hline \hline Under 6 months & 50 & $35.2 \%$ \\
\hline From 6 months to 1 year & 39 & $27.5 \%$ \\
\hline From 1 to 3 years & 26 & $18.3 \%$ \\
\hline More than 3 years & 27 & $19.0 \%$ \\
\hline Total & 142 & $100 \%$ \\
\hline
\end{tabular}

(Source: Analysis of survey data in 2019 by the author).

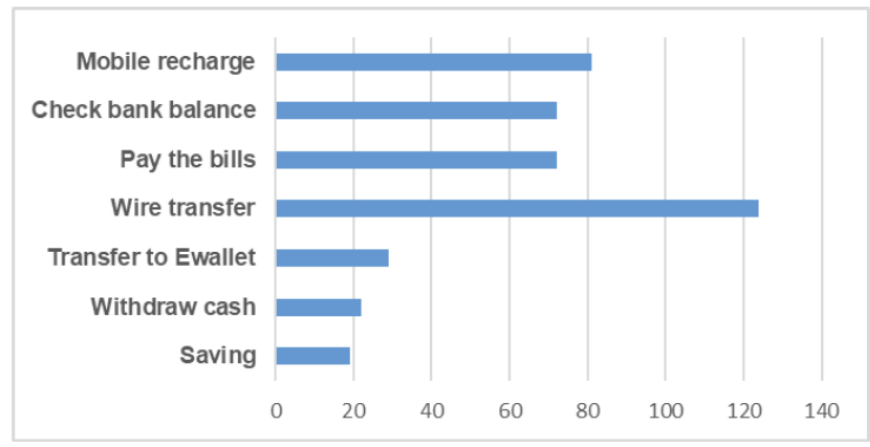

Figure 1: The most frequently used features of MB.

(Source: Analysis of survey data in 2019 by the author). 


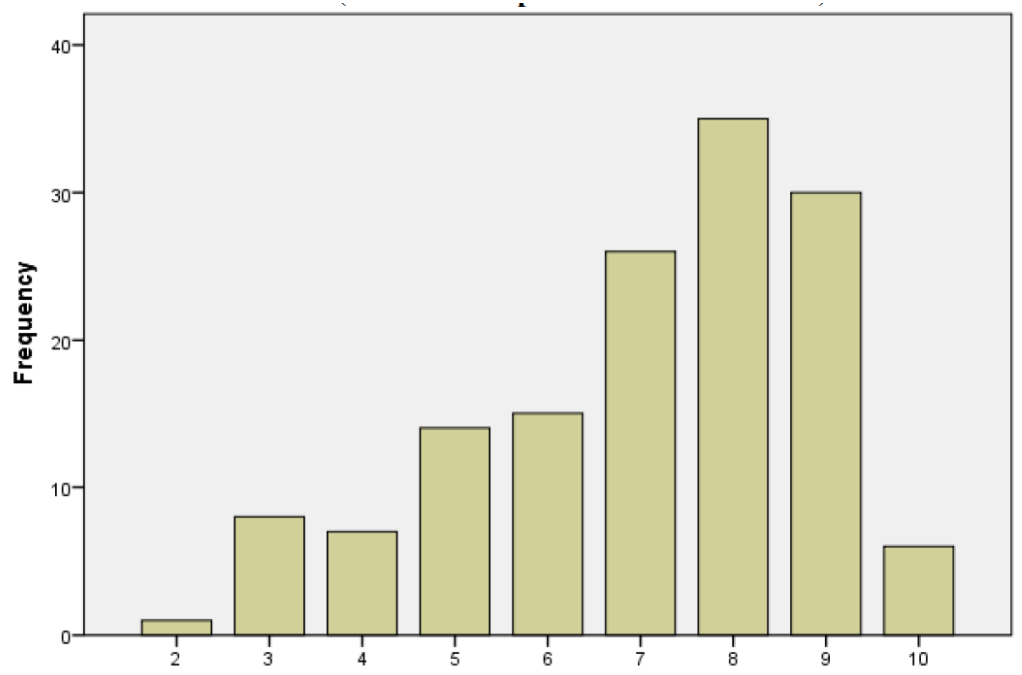

(Source: Analysis of survey data in 2019 by the author)

Figure 2: Percentage of banking transactions performed in MB (1-> 10 corresponds to $10 \%->100 \%)$.

(Source: Analysis of survey data in 2019 by the author).

Table 3: Descriptive Statistics

\begin{tabular}{|l|c|c|c|c|c|}
\hline & Sample size & Minimum & Maximum & Mean & Standard deviation \\
\hline \hline The bank transaction rate is made in MB & 142 & $20 \%$ & $100 \%$ & $70.8 \%$ & 1.874 \\
\hline
\end{tabular}

(Source: Analysis of survey data in 2019 by the author).

year, this shows the potential of the cashless payment market is huge and also has room to promote the growth. There is a great deal of growth and transition to a cashless economy in Vietnam.

Through the survey results, we found that respondents often use MB to transfer when up to 124 people, make up $87.3 \%$. This is also a popular form of transaction because of its fast and convenient characteristics. In addition, the other two utilities are using $\mathrm{MB}$ to check the balance and pay the bills are two utilities with the same usage rate of $50.7 \%$. $57 \%$ of respondents use $\mathrm{MB}$ to recharge their phones. Besides, the method of transferring money to e-wallets has just been implemented by the bank, so the number of people who know and use this is not high when only 29 people choose to use, accounting for $20.4 \%$. Respondents can also withdraw cash via this service, with 22 people making up 15\%. Finally, savings accounts on MB accounted for the lowest rate with 19 people, equivalent to $13.4 \%$ using this service.

\subsubsection{Banking transaction rate is done by Mobile banking}

The data obtained shows that the proportion of bank transactions made in MB accounts for a relatively high proportion with the average number recorded as $70.8 \%$. This has shown the important role of MB in the cashless economy. With the convenience and fast bringing, the development of MB will be able to help Vietnam move faster on the path of becoming a cashfree economy as the Government's goal.

\subsubsection{The Ratio of Non-Cash Transactions to Total Spending}

The results showed that only $50 \%$ of non-cash transactions were conducted on the total expenditure. This is a much lower number than the goal of $90 \%$ of non-cash payment activities by the end of 2020 . This result was done on a sample of people who used the MB app but this ratio is still very low, which shows that the government's next path to realizing its goal of becoming a cashless economy is challenging.

\subsection{Discussion and Proposed Solutions}

\subsubsection{Discussion}

Vietnam has linked the Better Than Cash Alliance (associated with the United Nations Capital Development Fund) and is actively realizing the Strategy for developing non-cash payment methods during 2016-2020 and to 2030. At the same time, 


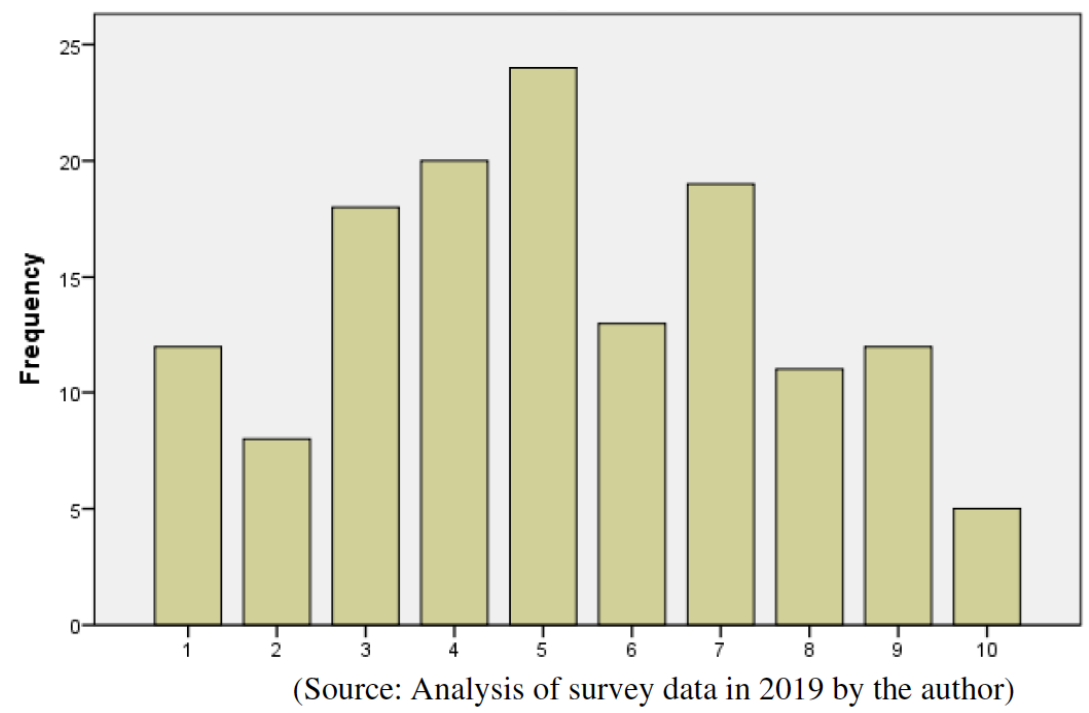

Figure 3: Percentage of non-cash transactions over total spending (1-> 10 corresponds to $10 \%->100 \%$ ).

(Source: Analysis of survey data in 2019 by the author).

Table 4: Descriptive Statistics

\begin{tabular}{|c|c|c|c|c|c|}
\hline & Sample size & Minimum & Maximum & Mean & Standard deviation \\
\hline \hline $\begin{array}{c}\text { The ratio of non-cash transactions to } \\
\text { total spending }\end{array}$ & 142 & $10 \%$ & $100 \%$ & $\mathbf{5 2 \%}$ & 2.463 \\
\hline
\end{tabular}

(Source: Analysis of survey data in 2019 by the author).

Vietnam is also taking part in the development of a Financial Strategy for people at the national level to promote access to financial formal regulations for the people, in which the development of The payment system is expected to be one of the essential elements. This shows the government's determination to modernize the nation's finances. The Government has also taken many active measures to implement the roadmap for building a cashless society by 2030 , such as developing new payment methods for rural areas to increase access to services. In 2020, the Government is aiming at least $70 \%$ of citizens over the age of 15 with a bank account. Government grants and social welfare systems are also being improved to ensure non-cash payments. In 2020, the goal is to reach 200 million transactions per year and at least 300,000 POS will be installed.

Along with infrastructure development, the Government also focuses on the security and safety of solutions to protect consumers. To minimize risks, the Government issued Circular No. 30/2016 / TT- NHNN in October 2016, providing regulations on payment service provision and intermediary payment services, including: provide regulations on security solutions, resolve complaints and ATM safety and legal rights for customers and users of payment services. (StateBank-of-Vietnam 2018)

Results from this study also showed that only about $52 \%$ of the study participants' payments were made not in cash. That means the remaining $48 \%$ of spending is in cash. Based on the survey sample, those who already have a bank card and know how to use noncash payment methods like Mobile banking, it can be seen that the road to the goal of $90 \%$ of transactions is not by cash in 2020 by the Vietnamese government will be very difficult, if not impossible, because $63 \%$ of Vietnamese adults currently do not own a bank account. Therefore, the government needs to adjust the target, or reduce the percentage of non-cash transactions, or delay the implementation of the target.

In addition, based on the results of the research, a large percentage of people use $\mathrm{MB}$ to perform the transfer and recharge functions of the phone because it is convenient and fast, which saves a lot of time and effort. This result also provides suggestions to further develop the use of $\mathrm{MB}$ among citizens, a very important tool of the non-cash economy, as provisions for free transfer when making money transfers via applications such as $M B$, to further enhance the 
promotion focus on the features most used will contribute to further promoting the dissemination of non-cash payment instruments, thereby increasing the proportion of non-cash payments on the total means of payment.

\subsubsection{Proposed Solutions}

Based on the analysis above, we also offer these following recommendations for implementing the goal becoming a cashless economy of Vietnam:

First, to promote cashless products, services and procedures for citizens and businesses, policymakers need to disseminate financial knowledge to help citizens and businesses. identify fraudulent acts, identify risks, prevent and handle when arising problems related to non-cash payment. Simplifying the use of non-cash payment for the reason is not a consumer habit but a cashless experience that is not really as convenient as using cash.

Next, it is necessary to expand the network of equipment to accept card payments at hospitals, schools, agency taxes, customs, social security payments ... and also to pay via bank transfer. In addition, make sure that all supermarkets, shopping center and distributors take this type of card. The state should control the upgrade and maintenance of the system, avoiding the software at the payment locations that fail, resulting in loss of money and loss of customer data.

Moreover, we need research to promote the application of modern technology in authentication solutions, customer identification by electronic means to enable banks to accurately identify customers, thereby developing new payment facilities, enabling customers to easily access and use non-cash payment services. Developing more and multi-purpose cards to allow the collection, payment, tolls, social insurance, tuition and hospital fees with different forms of payment. The State Bank also needs to implement more solutions such as checking the compliance with legal documents on electronic payment and card payment; complete the safety and security framework of the payment system, protect the legitimate rights and interests of customers and payment service providers and ensure that all ATM chip cards meet EMV standards (abbreviated of Europay, Mastercard and Visa) - a global standard for cards equipped with computer chip cards and the technology used to authenticate chip card transactions, in 2020 to minimize e-commerce risks for both buyer and seller.
At the same time, the government should encourage models of cooperation between banks and payment intermediaries to provide payment products and services compatible with public and payment services. specific social security. Expanding and developing the connection between banks and electricity, water, schools, hospitals and social insurance units to process and compare information in the form of electronic data, creating favorable conditions for fast and accurate monitoring and management of revenues and expenditures with customers. Build a channel to receive and process information online so that people can reflect, update fraud, fraud, fraud, measures to identify risks, prevent and deal with activities.

Macro management agencies such as the Government, the State Bank, the Ministry of Finance, and relevant ministries and branches should quickly issue regulations and policies to create a breakthrough for card payment services such as regulates the businesses that are required to pay via card, tax reduction/refund for card payment transactions so that people and business units must use non-cash payment facilities; exempt/reduce import tax on equipment used in card payment to reduce input costs for commercial banks and payment service providers.

\section{CONCLUSION}

Research has shown that the benefits of a cashless economy are huge: Banks reduce funding costs, the State also regulates and better controls the amount of money put into circulation, businesses control good cash flow. In particular, consumers are not only aware of the quick, convenient way to use a card or use a paid smartphone, but also by security and safety. However, in order to realize the government's ambitious goal of $90 \%$ of non-cash payments in Vietnam, it is necessary to continue improving the legal basis, payment infrastructure, and invest to improve quality and expand the scope. On the other hand, the work to ensure the security, safety and security of the payment system should be focused.

In summary, from the situation stated in the study, if Vietnam wants to target non-cash country, although the goal of $90 \%$ of non-cash payment in 2020 is almost impossible, policymakers still need to work closely with banks, local governments and businesses to be consistent in implementing the solutions proposed above. 


\section{REFERENCES}

Anh, T. (2019). "Non-cash payment is still entangled." Economics and Urban.

Betterthancash.org (2017). "The Role of Digital Payments in Sustainable Agriculture and Food Security."

Ejiofor, V. and J. Rasaki (2012). "Realizing the benefits and challenges of cashless economy in nigeria: it perspective." International Journal 1 (1).

Fox, KHJABLJ (1980). "Another step toward the cashless society? The 1978 federal electronic fund transfer act." 18 (2): 209224

https://doi.org/10.1111/j.1744-1714.1980.tb00041.x

Hasan, I., et al. (2012). "Retail payments and economic growth." https://doi.org/10.2139/ssrn.2100651

Hồng, L. (2019). "Vietnamese people still mainly spend cash." Great Solidarity.

Liao, W. and JJIJ o. BM Handa (2010). "Is the modern economy heading toward a cashless and checkless one? Evidence from the payments system in Canada." 9 (4): 48.

Medina, L. and F. Schneider (2018). "Shadow economies around the world: what did we learn over the last 20 years?". https://doi.org/10.5089/9781484338636.001

Mieseigha, EG and UK Ogbodo (2013). "An empirical analysis of the benefits of cashless economy on Nigeria's economic development." Journal of Finance and Account 4: 11-16.
Oyewole, OS, et al. (two thousand and thirteen). "Electronic payment system and economic growth: a review of transition to cashless economy in Nigeria." 2 : 913-918.

Rogers, EM (1995). Diffusion of Innovations: modifications of a model for telecommunications. Die diffusion von innovationen in der telekommunikation, Springer : 25-38. https://doi.org/10.1007/978-3-642-79868-9_2

Schneider, F. (2017). "Restricting or abolishing cash: An effective instrument for fighting the shadow economy, crime and terrorism?".

State-Bank-of-Vietnam (2018). "Amending and supplementing a number of circular regulations on the provision of payment services and payment intervention services."

Tee, H.-H. and H.-B. Ong (2016). "Cashless payment and economic growth." Financial Innovation 2 (1): 4. https://doi.org/10.1186/s40854-016-0023-z

Vũ, K. (2018). "In 2020, reduce the proportion of cash payments to less than $10 \%$." Vietnam Financial and Financial Times.

Wright, R., et al. (2017). "Less cash, less crime: Evidence from the electronic benefit transfer program." 60 (2): 361-383. https://doi.org/10.1086/693745

Zandi, M., et al. (two thousand and thirteen). "The impact of inequality on economic growth on economic growth." 1-16.

DOI: https://doi.org/10.6000/1929-7092.2020.09.20

(C) 2020 Hoang Ha; Licensee Lifescience Global.

This is an open access article licensed under the terms of the Creative Commons Attribution Non-Commercial License (http://creativecommons.org/licenses/by-nc/3.0/) which permits unrestricted, non-commercial use, distribution and reproduction in any medium, provided the work is properly cited. 